\title{
Conversa aberta: texto e musicalidade
}

\author{
Open talk: text and musicality
}

Maria Clara Ferrer (mediação, transcrição e edição)

Maria Clara Ferrer

Professora do Departamento de Letras Artes e

Cultura da Universidade Federal de São João Del

Rei. Encenadora, dramaturga e tradutora.

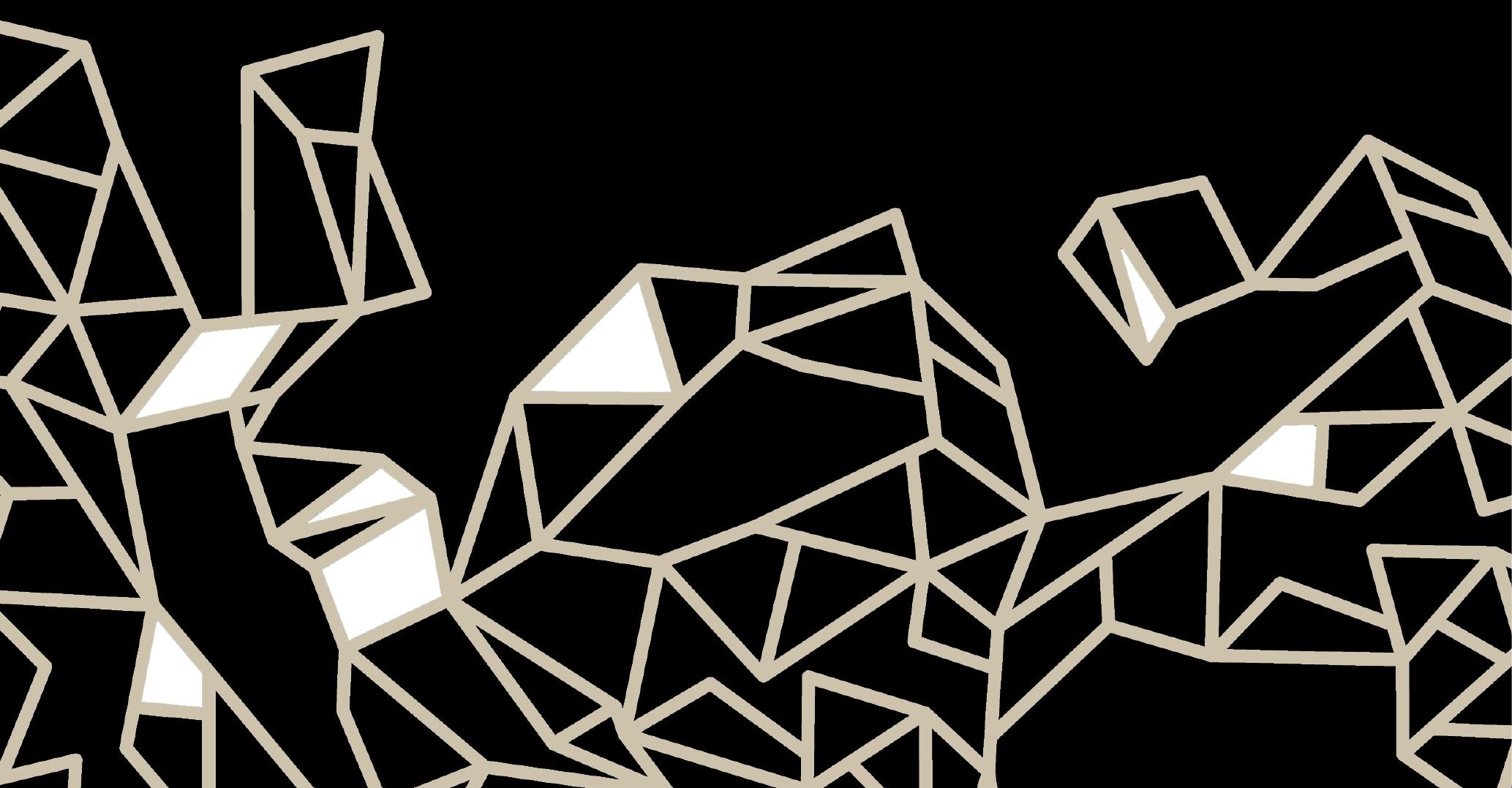




\section{Resumo}

Este texto é a transcrição da mesa redonda realizada no dia 4 de agosto de 2016, durante o evento "CASA ABERTA convida: Texto e musicalidade", na Sala Preta do curso de Teatro da Universidade Federal de São João Del Rei. Convidados e professores do curso elaboram uma reflexão aprofundada sobre um possível lugar de interseção entre a Música e o Teatro, sob as perspectivas da dramaturgia, da encenação, da atuação e da pedagogia teatral, em um diálogo permeado pelas noções de coro, escuta e silêncio.

Palavras-chave: Texto, Musicalidade, Escuta, Silêncio e Coro.

\section{Abstract}

This text is the transcription of the round table occurred in August $4^{\text {th }}$ 2016 during the meeting named "CASA ABERTA convida: Texto e musicalidade", that took place in the Dark Room ("Sala Preta") of the Theater Program of Universidade Federal de São João Del Rei (Minas Gerais, Brazil). Guests and professors of the program execute a deep reflection about a possible intersection between Music and Theater. The debate deals with text and musicality according to the perspectives of dramaturgy, direction, acting, and theater pedagogy, in a dialog permeated by the notions of listening, silence, and chorus.

Keywords: Text, Musicality, Listening, Silence and Chorus. 
Mesa redonda com Marcio Abreu¹, Ernani Maletta², Marcus Borja³ Juliana Mota ${ }^{4}$, Vinícius Albricker ${ }^{5}$ e Ana Dias ${ }^{6}$

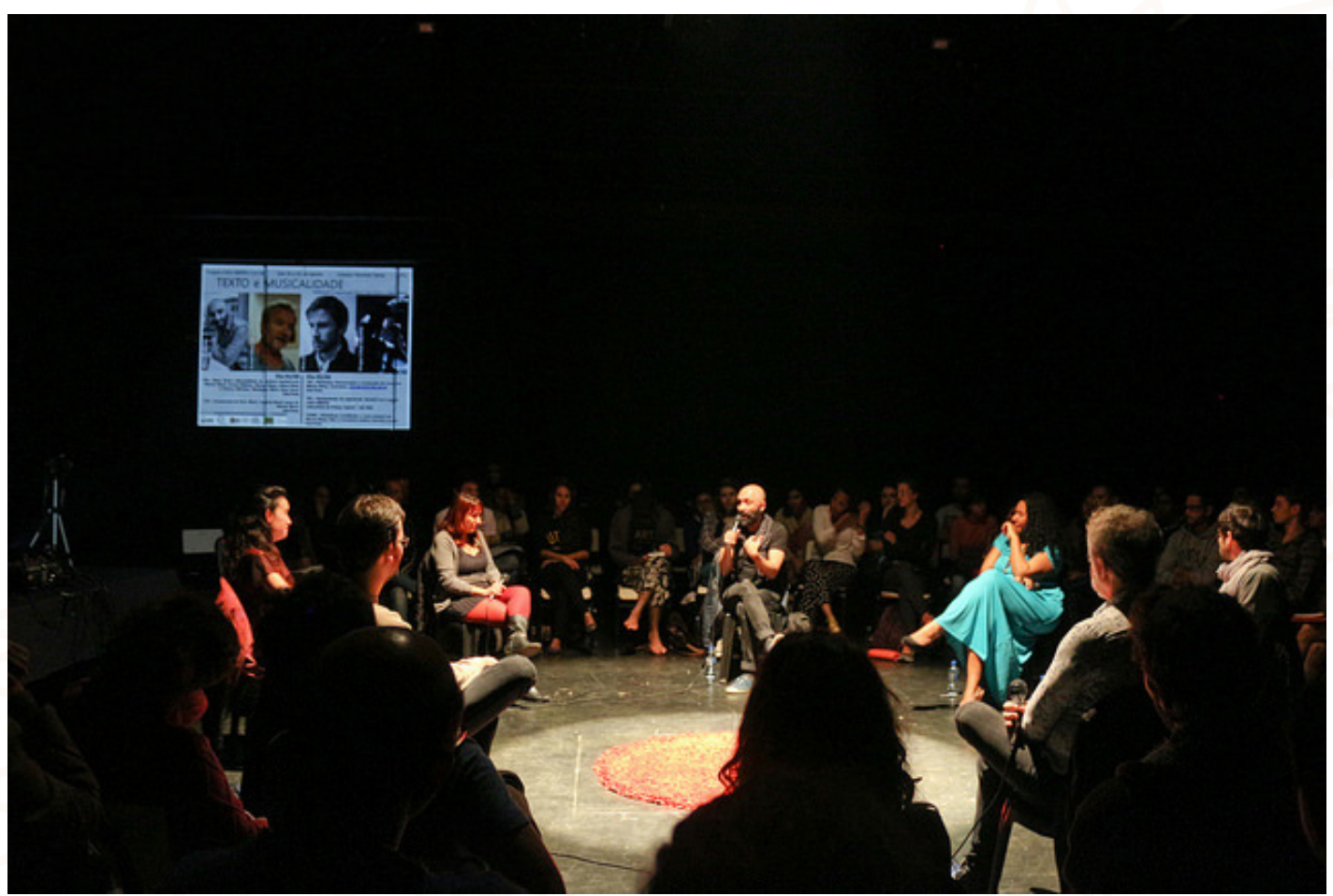

Evento "CASA ABERTA convida: Texto e musicalidade", 4 de agosto de 2016, Sala Preta do Curso de Teatro da Universidade Federal de São João Del Rei, Minas Gerais. Foto: Priscila Natany.

Maria Clara Ferrer: $O$ desejo de criar este evento surgiu com uma experiência de espectadora que compartilhei recentemente com os alunos do nosso curso, quando fomos a Belo Horizonte assistir a Nós, último espetá-

1 Marcio Abreu é dramaturgo, diretor, pesquisador e ator, fundador da companhia brasileira de teatro.

2 Ernani Maletta é diretor musical e professor-doutor do curso de graduação em Teatro e da pós-graduação em Artes da Universidade Federal de Minas Gerais.

3 Marcus Borja é ator, músico, regente de coro, doutor em Artes Cênicas pela Université Sorbonne Nouvelle Paris 3 e pesquisador-encenador do programa doutoral de arte e criação SACRE (Science, Art, Création, Recherche).

4 Juliana Mota é cantora, atriz e professora-doutora do curso de graduação em Teatro da Universidade Federal de São João Del Rei.

5 Vinícius Albricker é ator, músico, doutorando no Programa de Pós-Graduação em Artes da Universidade Federal de Minas Gerais e professor do curso de graduação em Teatro da Universidade Federal de São João Del Rei.

6 Ana Dias é cantora, atriz, doutoranda do Programa Pós-Graduação em Artes Cênicas da Unirio e professora do curso de graduação em Teatro da Universidade Federal de São João Del Rei. 
culo do Grupo Galpão, escrito e dirigido por Marcio Abreu. A curiosidade e o entusiasmo proporcionados por esta criação se traduziram, em seguida, em vivos debates e finas análises da peça em sala de aula. Um dos aspectos que ficaram mais nítidos nas reflexões levantadas pelos alunos acerca de Nós foi a importância da musicalidade que se manifesta tanto na escrita do texto quanto na atuação dos atores.

Buscando expandir e aprofundar a questão da musicalidade nas práticas teatrais, Juliana e eu quisemos convidar Marcio Abreu, Ernani Maletta preparador musical e criador dos arranjos vocais e instrumentais de Nós - e Marcus Borja - especialista da cena coral - para um tempo de diálogo com os professores e alunos do curso em torno dessa mesa-redonda. Esperamos que todos desfrutem intensamente desse momento de reflexão polifônica.

Prima la musica, dopo le parole. Prima le parole, dopo la musica. Assim se resumia a querela que agitou o mundo da Ópera nos séculos XVIII e XIX. Os compositores defendiam a supremacia da melodia sobre a palavra e os escritores, por sua vez, alegavam a hegemonia do texto sobre a música. A controvérsia deixa clara a relação de concorrência e de conflito entre o plano musical e o plano textual da representação. Romper com essa dicotomia foi um dos grandes desafios da arte teatral no século XX. E é sobre esse possível lugar de interseção e de diálogo entre texto e musicalidade que vamos nos debruçar hoje, levando em conta os pontos de vista da dramaturgia, da encenação, da atuação e da pedagogia.

Como uma maneira de se apresentar, eu queria pedir que cada um relatasse uma experiência de espectador ou experiência de vida que possa ter sido fundadora dessa relação forte entre Teatro e Música que caracteriza a trajetória de vocês.

Marcio Abreu: Boa noite! Antes de mais nada, gostaria de agradecer o convite da Maria Clara e da Juliana e agradecer também o fato de estarmos aqui em roda, acho isso bastante significativo. A roda é necessariamente um movimento, a circularidade jamais é estática. É interessante falar sabendo que tem gente ao redor, a gente se sente acolhido. Também queria dizer que estou bastante feliz de estar aqui e de encontrar um espaço como este nesta cidade. Dá uma certa esperança nas coisas, no mundo... mesmo em um país em ruínas como o nosso. 
Para falar dessa relação entre os campos do Teatro e da Música, eu vou contar uma anedota, uma coisa de infância, algo que talvez tenha ficado inoculado na minha experiência das coisas e do mundo e que, entre outras coisas, talvez seja responsável por eu tomar as opções que tomo como artista.

A memória é sempre uma mistura de recordação, de lembrança e de invenção. Jamais saberemos se o que eu estou dizendo aqui aconteceu ou não, ou sob qual aspecto isso aconteceu. Mas o fato de estar contando isso aqui estabelece, em alguma instância, a presença desse fato. A narrativa também cria a realidade, os campos da realidade e da ficção são relativos. Se eu narro algo que me aconteceu, isso se presentifica graças ao meu relato.

Eu era criança e morava no Rio de Janeiro. Tive a sorte de ter pais que gostam de Teatro e Literatura. Estava no Maracanãzinho assistindo a um show de patinação artística. Meus pais relatam um comportamento histérico que tive. Comecei a gritar e pular no meio do público e saí dali rouco. Lembro de uma cena muda, com um homem e uma mulher patinando em silêncio. De repente, todas as luzes do Maracanãzinho se apagavam e, quando acendiam novamente, entrava um som extraordinário, estridente. Essa passagem do silêncio para o som me causou algo inexplicável. Entender que tem esse lugar do silêncio e esse lugar que não é o que costumeiramente chamamos de silêncio foi essencial. Agora há pouco, no carro, vindo de Belo Horizonte para São João Del Rei com o Ernani e o Vinícius, falávamos da diferença entre pausas e silêncio... e eu tinha me esquecido desse momento no Maracanãzinho. Essa sua pergunta me fez lembrar disso.

Ernani Maletta: No final dos anos 1970, eu cantava em um coral e houve um evento muito significativo para mim. Eu sempre falo disso como um dos impulsos de toda a minha trajetória artística. Era um grande evento de corais no Palácio das Artes, em Belo Horizonte. Ali aconteceu um fato importantíssimo: um dos corais começou a cantar, mas não aparecia em cena. Era um coral da Newton Paiva, no qual eu entrei anos depois. Eles cantavam "Alguém cantando", do Caetano Veloso, com o arranjo famosíssimo do Marcos Leite, que virou um hino do Canto Coral nos anos 1970 e 1980. Aquilo era simplesmente óbvio e lindo. Eles entraram cantando pelos lados do teatro, com uma beca azul, que era o "uniforme" que eles usavam. No final da música, todos tiraram a beca: estavam de calça jeans com camiseta branca Hering, na qual 
estava escrito "Coral Newton Paiva". E eu estava de túnica vinho, que arrastava no chão... com um jabô de renda que vinha até a barriga... era tudo muito pesado. Segurava uma pasta cheia de plásticos vazios, porque a gente cantava tudo de cor e sem partitura, mas era muito chique ter uma pasta. Esse grupo pôs a pasta no chão e cantou na sequência o "Rock da cachorra", do Eduardo Dusek. Faziam um muro humano, com um jogo de cena simplíssimo, mas importante. Logo depois apareceu um coro da Polônia, de beca também. Eles se espalhavam pelo teatro inteiro, depois se agrupavam de formas diversas pelo palco, cantavam metade na plateia, metade no palco. Isso me fez entender, anos depois, porque, mesmo eu gostando muito, algumas vezes era para mim muito chato cantar em coral. Descobri que na partitura tradicional do coro não se escreviam as outras vozes que não são as melodias. As melodias são apenas algumas das vozes do canto coral, pois existem outras tantas vozes que são o movimento das pessoas, a luz que se acende, o figurino... todo esse conjunto é aquilo que manifesta no espectador o que ele está sentindo. E, mais uma vez, eu me lembro da nossa viagem de hoje, na qual falamos muito do que é sentir. Foi uma viagem bastante filosófica! Quando eu entrei no grande movimento do Canto Coral no final dos anos 1970, buscava-se aproveitar todos os discursos que estão entrelaçados nessa grande polifonia que é o evento coral. Isso vai além do som e da palavra. Mal sabia eu que, naquele momento, eu estava recuperando a origem do Teatro, ou seja, o coro. E a origem foi o coro porque era imprescindível, para a manifestação dessa arte, ser múltipla, ser um entrelaçamento de diversas formas expressivas. O coro se manifestava cantando, dançando e falando, como uma coisa só. A palavra "coreografia" vem de coro. Há historiografias que definem o coro como a forma original do Teatro. O que eu vivia naquele momento não era só a Música, mas uma experiência envolvendo uma quantidade enorme de coisas. Muitos anos mais tarde, fui finalmente entender essa diferença. Para que o Teatro se manifeste é imprescindível que ele tenha na sua composição diversas matérias primas, de diversas ordens. Para ser Teatro há de haver um entrelaçamento de matérias primas. Eu não posso eleger uma matéria prima como mais importante que as outras. Então consegui perceber a diferença entre Música como arte autônoma e o discurso musical que faz parte do Teatro, que é intrínseco a ele. 
Uma coisa muito importante para mim é entender a diferença entre o substantivo "Música" e o adjetivo "musical." Um belo dia, no passado, o nome "Música", Mousiké, não era exclusivo da arte Música, era um campo do conhecimento, do logos, que envolvia toda as formas de organização do pensamento. Aconteceu que essa grande esfera do conhecimento se esfacelou e suas partes ganharam nomes específicos: uma parte virou Dança; outra, Teatro... e outra permaneceu Música, ou seja, ficou com o mesmo nome. Se essa parte hoje se chamasse, em vez de se chamar Música, se chamasse "Sonora", seria ótimo. Teríamos a Dança, a Poesia... e a Sonora. Tanto o "sonorista" quanto o poeta, quanto o dançarino, passariam em suas formações por questões musicais, que têm a ver com todos. E a Sonora trataria os conceitos musicais de forma particular...

Não é o caso de pegar emprestado da arte Música conceitos para colocar no Teatro. Foi isso que aquele momento despertou em mim: aquilo que essas pessoas estão fazendo aqui não é só música, mas uma manifestação do que eu considero Teatro. Isso foi para mim a grande virada, que aconteceu naquele dia e naquela época...

Ana Dias: Toda vez que vou dar aula de musicalidade, tenho dificuldade em explicar o que é musicalidade. A sua pergunta me fez lembrar quando eu estudava piano, devia ter uns dez anos. Era boa de ouvido e de memória, mas detestava partitura. Um belo dia, minha professora falou que eu ia aprender o "colorido" da música. Ela foi me ensinando a tocar mais suave, a descobrir uma dinâmica musical, e a música foi se transformando. Eu, que gostava de tocar tudo muito rápido e com a mesma intensidade, a partir daí comecei a entender as nuances. A possibilidade de criar um discurso com pequenas e grandes surpresas, uso elaborado do ritmo e da intensidade, é o que se pode trazer para as artes que se articulam no tempo (a Música, o Teatro, a Dança, o Cinema...). Isso tem a ver com o movimento do som e com o movimento no espaço. Isso é o "colorido"!

Marcus Borja: Enquanto ouvia atentamente, fiquei buscando aqui na minha memória qual poderia ser o momento desse despertar. Mas não achei! Talvez porque isso tenha se feito por dois caminhos paralelos, que são o da arte musical e o da arte teatral. Iniciei a Música mais cedo e de maneira mais oficial com uma trajetória no Conservatório Brasileiro de Música do Rio de 
Janeiro. E comecei a tomar aulas de Teatro depois, aos quatorze anos, no Tablado, mesmo que desde muito pequeno o Teatro já rondava a minha vida. Com meus irmãos e primos, criar peças sempre foi uma das nossas maneiras prediletas de inventar mundos.

Existem dois momentos nos quais esses dois caminhos se cruzam.

O primeiro deve ter sido quando tinha uns cinco anos. Estava no jardim da infância. Tínhamos aula de Música, ou seja, formávamos uma bandinha de percussão. A professora pôs sobre um tapete vários instrumentos. E cada aluno devia escolher e pegar o seu, o que é um pouco complicado quando você é o menor da sala. Eu queria o tambor, mas quando consegui me aproximar do tapete, tinham sobrado somente três clavas, só que éramos dois sem instrumento ainda. Resultado: fiquei com uma clava só. Então a professora me falou: "você não quer ser o maestro?". Achava estranho porque não ia tocar nenhum instrumento, mas aquilo acabou se tornando uma maneira de escutar melhor todos aqueles sons. Isso me acompanhou durante muito tempo. Essa brincadeira de ler música através do gesto foi a primeira forma de reunir Teatro e Música. Quando eu regia, eu podia ouvir a arquitetura musical.

O segundo momento desse encontro foi a descoberta da Ópera aos dezesseis anos... foi uma paixão meio fulminante. Tem uma palavra que tem a ver com a ligação entre a regência, o gesto e a Música. É a palavra "tradução". Jacques Rancière fala que uma comunidade ideal é uma comunidade de contadores e tradutores. Tradução me parece uma noção boa para entender a questão da musicalidade. $O$ fato de dizer que existem princípios musicais que são comuns ao Teatro, à Literatura, à Dança, não diminui essas artes. Eu acho que esse mecanismo tem a ver com tradução. Na Ópera o que me intrigou foi a capacidade de construir sentido, desenvolver dramaturgias, avançar em narrativas e elaborar situações simultaneamente e de maneira contrapontística. Acho que o teatro é capaz disso também, mas essa não parece ser sua preocupação essencial, pelo menos não do teatro dramático. A cena está escrita daquele jeito, com as falas impressas umas depois das outras, então achamos que temos que falar assim. As falas nunca se sobrepõem. Eu espero que uma pessoa acabe de falar para começar a minha fala, não há um risco de escuta generosa e insolente. É uma escuta preguiçosa, de espera, uma mera transcodificação do escrito para oral. Na Ópera, a simultaneidade não 
cria problema, porque a harmonia dá conta disso. E a harmonia não é um conceito exclusivo da Música.

Um exemplo perfeito e bastante famoso é o quarteto do quarto ato do Rigoletto, do Verdi. Temos um barítono, um mezzosoprano, um soprano e um tenor. São dois casais conversando ao mesmo tempo, um do lado de dentro e o outro do lado de fora da taverna, ou seja, em dois espaços diferentes. Um casal está do lado de fora e o outro, do lado de dentro. A música dá conta desse problema espacial e de discursos simultâneos, o casal de fora não precisa se calar para que o casal de dentro fale. É lindo... Se eles conseguem fazer isso na Ópera, pode-se fazer isso no Teatro também. Eu acho que é somente uma questão de escuta, eu posso escutar alguém ao mesmo tempo em que falo. Eu não perco a autonomia da minha fala porque estou ouvindo. Como numa polifonia.

Vinícius Albricker: Por acaso, hoje no carro eu contei um desses pontos de virada também. Meu pai é músico, trompista. Quando minha mãe estava grávida de mim, ele colocava a campana da trompa na barriga da minha mãe. Eu me lembro... A trompa é um instrumento que apesar de muito aveludado, pode ser muito forte e poderoso. Acho que isso ficou em mim porque sou apaixonado por contrastes, isso é muito presente na minha vida artística e pessoal.

Nas férias eu ia para os festivais da UFMG visitar meu pai, que é maestro, bandleader da [Gerais] Big Band. Os inícios dos shows da Big Band sempre me impressionavam. Eu era garotinho. Eles entravam pelos lados da plateia, sem partitura, tocando "Pantera cor de rosa", jogavam e brincavam. Meu pai regia, pulava, dava coices. Depois eu tive a oportunidade de tocar na Big Band. Uma das experiências mais fortes que tive foi fazer um solo improvisado de guitarra com a Big Band. A experiência da escuta, que o Marcus salientou, ficou muito nítida em mim naquele momento. Também era muito prazeroso "fazer a cama" para os outros improvisarem. Comecei a escutar músicos que me marcaram muito, como Hermeto Pascoal; o que ele faz é um espetáculo! O poder do som é algo que me fascina. Um único som já carrega em si várias tensões. Acho que a relação entre música e texto, que é intrínseca, é antes de tudo um jogo de tensões.

Juliana Mota: A primeira experiência forte para mim vem de uma parte da família que ainda está bastante vinculada à tradição oral... isso em Minas é muito frequente. Eu venho de uma família de negros e tem uma parte dela, 
do lado do meu pai, que é de uma irmandade de congado. Essa origem do coro que estamos relembrando aqui se manifestou pela primeira vez no meu corpo na festa de Nossa Senhora do Rosário, vendo as várias guardas que dançavam e tocavam coisas diferentes ao mesmo tempo. Aquilo gerava em mim uma sensação de pertencimento, de estar viva, de estar presente, é algo que recupero toda vez que eu estou em cena. Essa experiência musical ampla faz parte da minha trajetória.

Tenho uma clareza muito grande de quando via um tio ou uma pessoa da irmandade cantando, mesmo sem entender o que eles falavam. Eu via que não era uma pessoa cantando, tinha um discurso ali dentro, tinha uma história, um texto, um corpo, uma situação que se estabelecia entre as pessoas. Isso era muito maior do que eu sentia sonoramente.

Quando vovó cantava, muito mais do que o texto dito, era o que aquela voz, o que a energia que emanava daquele corpo trazia para mim. Eu fui lembrar disso quando estava na faculdade, foi aí que eu consegui enxergar o quanto isso me atravessou. Descobrir isso dentro de mim foi uma potência. Uma potência porque ela parte de uma experiência muito viva, muito orgânica e compartilhada, porque é a história, em grande parte, do que forma esse povo brasileiro.

Maria Clara Ferrer: Agora que já estamos aquecidos, eu queria em primeiro lugar questionar como essa relação entre texto e musicalidade afeta ou pode afetar a produção dramatúrgica. No seu caso, Marcio, você começa encenando peças de teatro, muitas delas de autores franceses: Suíte 1, de Philippe Minyana, Apenas o fim do mundo, de Jean-Luc Lagarce, Isso te interessa?, de Noëlle Renaude, e, mais recentemente, Esta criança, de Joël Pommerat. Todas essas escritas apresentam, me parece, uma construção de natureza musical. Como esses textos com os quais você conviveu como diretor afetaram ou influenciaram o seu trabalho de escritor?

Marcio Abreu: Na verdade, foi um pouco o caminho inverso. Eu cheguei em alguns desses autores por conta de uma vivência e de uma busca no Teatro, inclusive como autor, ligadas às questões que estamos discutindo aqui.

Desde muito cedo, a palavra falada, os discursos ou até mesmo a fala de um ator no Teatro foi de muito difícil acesso. Sempre tive, e tenho, muita dificuldade em ouvir um ator em cena. Não está dado que o fato de que al- 
guém fale de maneira fisiologicamente clara e audível no palco crie a priori a dimensão da escuta. A escuta é relacional, tem a ver com o outro, com a alteridade, com a percepção e a manifestação de existência numa dimensão relacional. De uma certa maneira, escutar sempre foi um exercício árduo para mim. A escuta tem um lugar quase prismático no meu trabalho. Tudo o que eu faço me leva à questão da escuta, e, quando eu chego nela, abrem-se outras questões.

Eu comecei a ler muito cedo os antigos, Homero, por exemplo. A llíada é uma obra que justamente não separa Poesia, Música, Teatro, todos os sentidos estão implicados ali e amalgamados numa obra que soa. É muito comum encontrar traduções de Homero somente em prosa, o que é uma aberração, seria como ouvir uma música sem harmonia ou sem melodia.

Historicamente, há uma ruptura na história ocidental entre a Antiguidade e a Idade Média. O cristianismo criou um muro, um abismo entre todos esses elementos que, juntos, formavam a grande poesia, e depois desse abismo o que chega até nós - isso já é mais cartesiano - é a necessidade de ver o mundo através de compartimentos. A palavra chega até nós de maneira muito limitada, contaminada, vitimizada pelo campo da cultura. Você fala o que falam por você, diz sem saber o que já foi dito, como se uma "falange" falasse por trás de você. Quem lida com a palavra num campo qualquer de articulação e de linguagem não pode se colocar nesse lugar da vítima. Como você se livra desse aprisionamento da palavra no campo da cultura para acessar a palavra em um outro lugar, que pode ser o lugar da arte, da invenção e da escuta? Como recusar o lugar de poder da palavra? Essa é uma constante no meu trabalho, um fato diário. Para mim, tem uma reflexão da qual não posso desviar, que é: como você usa a palavra no campo da linguagem e entende que a palavra culturalmente é um lugar de poder. Exemplos na história não faltam, todo o nazismo foi construído através do poder da palavra.

Tem um antropólogo francês chamado Pierre Clastres, que fez um estudo sobre as tribos indígenas no Brasil. Ele descreve que, na maior parte das etnias, a ideia de chefe é completamente diferente da nossa. Por exemplo, ao fim do dia o chefe da tribo deve dirigir a palavra à população. Mas quando ele começa a falar, a comunidade finge não escutar, fazem outra coisa para manifestar a consciência coletiva de que a palavra não pode jamais 
ser confundida com o poder. A aparência do chefe é a mais pobre, a mais desprovida de ornamentos. Quando alguém Ihe pede alguma coisa, ele tem que dar. Nós aprendemos bastante com os índios, não é? Essa perspectiva de imaginar que a palavra está em outro lugar, que a palavra é o canto na poesia antiga, nas epopeias onde a narrativa e a música são indissociáveis, essa consciência fez, de certa maneira, com que eu articulasse isso ao meu trabalho teatral. E esse trabalho me levou a determinados autores. O campo da dramaturgia e da encenação são bastante indissociáveis. Pegando carona no que o Ernani falou, a encenação é um texto que se inscreve no corpo, no espaço e na experiência da alteridade, um homem diante dos outros. Essa perspectiva da encenação me levou à dramaturgia.

Essas práticas e estudos sempre foram permeáveis. Eu sou muito ligado à Literatura, comecei adaptando Literatura e depois escrevendo. Também fui influenciado pela experiência de estar perto da França. $O$ primeiro autor francês que montei foi Philippe Minyana, uma peça dele chamada Suíte 1. Ele, como Noëlle Renaude, são, de certo modo, herdeiros do Michel Vinaver e, indo ainda mais para trás, de Beckett. São autores que distendem a palavra num diálogo com o real, sem que haja necessidade de reproduzir uma realidade. Eles buscam promover sentidos a partir das sonoridades. São textos, portanto, que não sobrevivem sem a oralidade, como a maioria dos meus textos. Dramaturgias como Maré ou PROJETO bRASIL entendem que os campos sonoros são essenciais para que a experiência do teatro se complete corporeamente na oralidade.

Isso alimenta uma discussão importante no teatro contemporâneo: o que é publicável ou não? O que é a literatura teatral? Qual é o suporte daquilo que você inscreve no espaço? Como você registra uma experiência? A dramaturgia não cabe em um único aspecto. Na nossa já mítica viagem entre Belo Horizonte e São João Del Rei viemos ouvindo Arvo Pärt. A música no CD é somente um aspecto da experiência, assim como a publicação de um texto de Teatro contém um único aspecto da experiência teatral. Como dar conta, numa articulação de escrita, dessa experiência? Esse é um grande desafio.

No caso do PROJETO bRASIL, eu tinha um roteiro interno, um conjunto de códigos indecifráveis e unicamente internos. No momento da publicação do texto, eu tive um trabalho posterior voltado para o outro, um trabalho de tradução daquela experiência. Originalidade e autenticidade são termos 
que eu associo a condutas de exceção do homem. Toda a base do pensamento nazista consiste em excluir o outro em nome de uma originalidade. Não acredito em originalidade e autenticidade na arte, sempre é questão de tradução. Foi assim que os autores foram me levando a outros, mas sempre no fluxo de um processo criativo contínuo e subterrâneo. Eu não tenho tempo de escolher um texto para montar, esses textos acabam chegando a mim porque isso tem a ver com uma pesquisa que é permanente.

Ernani Maletta: Marcio, você toca numa questão fundamental que é a de que nós nunca vamos ter acesso à ideia que está na cabeça de uma pessoa que a traduziu em palavras e pôs no livro.

O Teatro é em si uma unidade, ele é a ideia entrelaçada de vários pontos de vista simultâneos sobre a mesma coisa. No Teatro, temos a ousadia de reconstruir, em uma unidade, algo que se apresenta a nós de maneira esfacelada. O problema é que temos que adivinhar como é que essas peças separadas poderiam estar entrelaçadas, na unidade de sua manifestação. Imaginemos que um espetáculo de Teatro seja uma escultura. Quando começamos o processo de montagem, é como se nos fosse apresentada essa escultura quebrada em pedacinhos e temos que remontá-la de modo que o espectador não perceba que ela estava quebrada.

Não existe palavra falada no nosso cotidiano que não tenha uma melodia. Quando eu falo, estou manifestando esses dois elementos como uma unidade, isto é, eu não preciso pensar na palavra separadamente da melodia e juntar uma coisa com a outra. Existe o desejo de manifestação de um certo ponto de vista que faz com que o meu organismo inteiro apresente a palavra expressa de certo modo melódico. O nosso problema com texto e musicalidade, no processo de criação cênica, é que a palavra escrita no papel tinha uma musicalidade na cabeça da pessoa que a escreveu, mas quando a lemos a gente não tem acesso a essa musicalidade e, assim, não sabemos exatamente qual é o seu ponto de vista. Na fala que é produzida por alguém que deseja manifestar alguma coisa, a palavra e som surgem juntos, enquanto que, quando eu leio a palavra escrita, eu imagino o som que eu quiser.

Marcio Abreu: $\mathrm{O}$ que tem de maravilhoso tanto na escrita musical quanto na escrita dramatúrgica é que você pode criar códigos e visualidades que de alguma maneira indiquem uma sonoridade. 
Ernani Maletta: $O$ que é fundamental não é que a palavra do texto seja dita por todos que a leem com a mesma sonoridade. O interessante é o pacto de reconstituir a unidade palavra-som e, se a minha unidade são for igual à sua, não tem problema. A palavra não estava na cabeça do autor que a escreveu como um simples conjunto de letras, ela tinha um corpo sonoro muito mais complexo. Por que havia a briga entre a palavra e a música na ópera no século XIX? Porque, muitas vezes, a melodia era composta num determinado aspecto e a palavra em outro. Depois as duas eram superpostas. Então havia, de fato, uma guerra entre o movimento melódico e o que está sendo dito. $\mathrm{Na}$ Itália, todas as óperas, cantadas em italiano, têm legenda. Ninguém entende nada. Porque a pessoa que escreveu a melodia não a escreveu para o que estaria sendo dito. Quando falamos de texto e musicalidade, estamos separando coisas que não deveriam ser consideradas separadas.

Marcus Borja: Várias lebres que estão sendo levantadas aqui. Isso tudo ressoa muito na minha própria experiência.

Queria retomar a questão da palavra, voltando ao primeiro impulso da nossa discussão que a Maria Clara deu, citando a querela italiana. Eu acho que a briga se resolveria se a gente pensasse a palavra como música e a música como veiculadora de sentido. Isso me faz pensar em um debate recorrente na França a respeito dos textos de Teatro em versos alexandrinos. Temos duas escolas: uma que dá prioridade à musicalidade, às doze sílabas, deixando a palavra para o segundo plano, e outra escola que se preocupa com o conteúdo semântico. É um casal que nunca vai se entender enquanto não se compreender que a palavra já é música e que a forma já é conteúdo.

Tenho dificuldade em prestar atenção em um ator no teatro quando ele acha que o que está dizendo é algo importante, como se estivesse pregando a boa palavra, ou como se estivesse ali para me ensinar alguma coisa. Esse tipo de teatro para mim é suspeitamente jesuíta e não leva em conta o que há de mais essencial no ato teatral: a relação.

Assisti, nos últimos tempos, a espetáculos lindos, até que o texto chegasse. Todos os elementos estão ali formando um todo, um texto, no sentido etimológico, ou seja, um tecido, uma trama. De repente um ator começa a falar e tudo desmorona como se agora fosse a vez do texto e que todas as outras vozes devessem se calar. Isso está ligado ao fato de se pensar o texto 
escrito como único veiculador possível do sentido inteligível. É como se o texto entrasse para dar conta de um sentido de que todos os outros elementos reunidos não fossem capazes. É uma dupla violência, primeiro com os outros signos, e em seguida com o próprio texto que perde a ocasião de ser tudo o que ele é, ou seja, mais do que pura semântica. Tem um texto lindo do Jean-Luc Nancy chamado À escuta, onde ele fala do sentido sensato e dos sentidos sensíveis. Quando damos ao texto o lugar do poder, do guardião absoluto do entendimento, o seu sentido sensato é sobrecarregado em detrimento dos sentidos sensíveis.

Os atores franceses, por exemplo, ficam desesperados quando ainda não têm texto. Por que a luz pode chegar três dias antes da estreia e não o texto? Se a gente faz uma roda de samba aqui, cada qual com um instrumento, sabemos cada um a potencialidade do seu instrumento e das possíveis relações entre eles. Vamos tocar e ver o que acontece. De repente, tocando "Naquele tempo", do Pixinguinha, alguém cita "Aquarela do Brasil" e um outro cita Amy Winehouse. A harmonia dá conta disso, a partitura não precisa estar escrita.

Juliana Mota: Criar esse vocabulário comum é o que há de mais difícil no Teatro. Existe uma base muito sólida na Música. Ainda estamos construindo essa base no Teatro. A sensação que eu tenho é que essa capacidade de fugir e voltar do texto é menor, porque não temos uma "escalinha", uma base clara na cabeça para saber o que eu posso colocar em jogo.

Marcus Borja: Eu entendo, mas essa base para mim é a escuta. Acho que é assim que eu chamaria essa "escalinha". No espetáculo Théâtre, que criei em 2015 no Conservatório Nacional de Arte Dramática de Paris, tentamos revitalizar essas questões. São cinquenta atores, trinta e quatro línguas, ou seja, o sentido sensato já se foi desde o início. O espetáculo acontece no escuro total, todas as fontes de luz são "tampadas." A dramaturgia vai muito além do texto escrito; tecer todo material literário, musical, epistolar, orgânico que levantamos foi a tarefa mais difícil do processo. Como transformar isso tudo numa forma, em um objeto que vai entrar em relação com pessoas que não acompanharam o processo, estender um fio que ponha em relação os atores e os espectadores? A construção dramatúrgica busca ativar, disponibilizar códigos que possam fazer com que aquelas pessoas que não acompanharam o processo entrem em relação conosco de igual para igual. Isso não 
quer dizer que todo mundo vai cantar junto, até porque existe uma potência do espectador que é necessária como um contraponto da potência do ator. A dramaturgia entra como a abertura de uma possibilidade de relação com o ator, essa dramaturgia não é nem diegética, nem narrativa, mas musical. Eu posso fazer ouvir ao mesmo tempo um lied com o texto de uma mulher que está sendo estuprada e pedindo para parar. Tem ali um diálogo possível. Como naquela frase do Paul Éluard que diz "a terra é azul como uma laranja", é possível dizer isso sim. E também é possível fazer dialogar em cena pessoas que a priori não poderiam dialogar. A musicalidade permite isso. $E$ não é um problema tão grave se a gente não entende as palavras, porque a musicalidade dá conta de produzir o sentido.

Maria Clara Ferrer: Referindo-se às diferenças entre a prática da Música e do Teatro, vocês falaram da necessidade de construir uma "escalinha", como vocês dizem, ou seja, uma qualidade de escuta que seria o fundamento, a base do trabalho do ator. Como vocês abordam isso em suas práticas pedagógicas, na formação e na direção dos atores?

Marcio Abreu: Fico pensando que um processo criativo não é nunca o caminho que se faz entre uma ideia e a concretização dessa ideia, como se eu projetasse tudo antes, e que o processo fosse o caminho para materializar o que foi pensado a priori. Quando eu vejo indícios dessa maldição, eu tento criar estratégias para transformar isso em outra coisa. Esse trabalho requer dos intérpretes um pensamento maior a respeito da dramaturgia. É claro que cada projeto artístico tem prerrogativas diferentes, cada criação tem o seu campo e códigos, novos ou velhos, que se renovam. Mas posso dizer que eu trabalho com uma permeabilidade entre a presença e a dramaturgia; muitas vezes essas coisas se confundem. Muitas vezes a dramaturgia e a manifestação da presença são a mesma coisa. Para cada ator existem caminhos diferentes para se chegar nisso... Tenho uma relação diferente e especifica com cada um. Se são dez atores, serão dez relações diferentes.

Ernani Maletta: A minha vida tem sido criar estratégias pedagógicas para trabalhar com determinados conceitos que o Teatro compartilha com outras formas de expressão, mas sem serem emprestados dessas formas de expressão. Não vou ensinar Música para o ator como o músico aprende na escola de Música; devemos aprender música no Teatro da forma que o Teatro precisa da músi- 
ca. Acho um absurdo que, até hoje, as pessoas considerem que cantar é cantar como músico e tocar instrumento é tocar que nem músico. Se alguém disser que não pode tocar piano, ou é porque não quer, ou porque não tem mão, nem dedo, nem nada. Para tocar piano basta debruçar uma parte qualquer do corpo sobre ele. Isso não é absurdo! Sai um som. Dei uma aula onde dezoito alunos tocavam uma partitura original do Arvo Pärt no piano. Cada um tocava uma única nota e estavam todos em volta e em cima do piano. Eles tocaram assim e foi lindo. Tinha um movimento coreográfico lindo ali.

Marcus Borja: Na verdade, não é só uma nota, mas todos aqueles movimentos que fazem a música acontecer.

Ernani Maletta: O que a gente criou ali foi uma unidade, um corpo. O problema maior é que a gente insiste em trazer para o universo teatral conceitos que são de outro universo, tentando reproduzi-los. Eu não posso cantar como cantor no teatro a não ser que meu personagem seja cantor, ou que a gente acrescente uma frase no texto do Shakespeare, dizendo: "Onde está o Hamlet? Está na aula de canto!.' Por que Hamlet haveria de cantar como um cantor lírico?

Muitos dos bailarinos clássicos virtuosos não conseguem atuar livres do balé porque estão presos, seus organismos estão condicionados pela estética da dança clássica. Para pegarem uma fruta no Sacolão precisam fazer um plié.

Marcus Borja: Isso que o Ernani diz me lembra uma passagem famosa de $O$ ser e o nada do Sartre, a do "garçom de café". O autor está num café e repara na maneira como o garçom carrega a bandeja, como ele pergunta se o cliente está satisfeito, como ele limpa a mesa. Tudo é feito como se ele sempre exagerasse um pouco, ele age fora da necessidade concreta e imediata da função dele. Então Sartre diz: "ele representa o garçom de café". Não basta para ele o contracheque no fim do mês, não basta acordar cedo, não basta o endereço do bar, a mecânica capitalista na relação patrão-empregado para que ele saiba e se sinta garçom, ele precisa, para que ele próprio possa se convencer de ser garçom, exagerar aquela função. Eu diria que isso também é um vício dos atores. Existem atores que precisam representar que são atores, isso passa antes da relação real do palco e dificulta muito o trabalho da escuta do outro.

Eu procuro no meu trabalho desvincular a escuta desses vícios. O primeiro passo é fazer silêncio, não como uma atitude passiva como se o as- 
sunto tivesse acabado. Duas pessoas compartilhando e produzindo generosamente um silêncio é uma grande prova de amor. Eu estou te dando o meu silêncio e recebendo o seu... é lindo! Esse silêncio não tem a mesma materialidade do silêncio parasita, porque o silêncio parasita é impregnado do "o que eu vou dizer?" ou do "passou um anjo." O silêncio que não contém a necessidade de fazer um discurso já implica uma responsabilidade de escuta coletiva que foi produzida por aquele silêncio.

Meyerhold dizia: "Eu trabalho muito melhor com atores que conhecem a música, raros são os que entendem que a música é o melhor organizador do tempo e do espaço no teatro. Ela pode não se fazer ouvir mas ela deve sempre se fazer sentir". Para trabalhar isso, o canto coral polifônico e contrapontístico é uma ferramenta muito importante para os atores. Para que um coro dê certo é preciso autonomia e generosidade ao mesmo tempo. Existem dois perigos: se deixar contaminar pela voz do outro e perder sua própria ou tapar os ouvidos para ouvir somente a sua voz e perder a voz do outro. Enquanto eu não percebo a voz do outro como algo que vai dar sentido à minha e o intervalo, o espaço de relação criado entre a minha nota e a do meu parceiro, não há escuta. $E$, consequentemente, não há teatro.

Ana Dias: Essa questão da escuta ficou muito clara para mim quando eu estudei cinema. Eu prestava muita atenção na relação entre o som e a imagem, eu percebi que o som no cinema não era para ser escutado, eu criticava muito o cinema clássico narrativo e a maneira como o som sustentava a imagem. Uma vez trabalhei a partir de um texto do Edgar Allan Poe que fala do cuidador de um idoso que ouvia demais. Ele escuta tanto que fica perturbado e mata o velho, corta o seu corpo e esconde no assoalho, mas continua ouvindo o coração do morto. No vídeo que eu fiz inspirado por esse conto, eu queria que o espectador fosse obrigado a ouvir.

Isso me fez pensar que uma coisa que a gente tem em comum é a capacidade de percepção do ritmo, essa é a base para a escuta e é o que leva o espectador a jogar junto com o artista. O ritmo não é um fluir contínuo, ele tem intermitências, e, quando percebemos essas intermitências, podemos jogar com a expectativa da espera. O ritmo é biológico, é a pulsação do coração, da respiração. No trabalho pedagógico a primeira coisa é fazer as pessoas pararem e escutarem, parar para escutar. 
Vinícius Albricker: Eu fico achando que às vezes reduzimos a noção de escuta ao fato de se calar, nesse sentido a noção de contraponto da qual o Marcus falou me parece essencial. Sobre isso eu queria contar uma anedota. Uma grande amiga minha da tradição sufi me deu um livro de presente com histórias de Nasrudin, que é um mestre às avessas da tradição oral sufi. Um dia um de seus discípulos Ihe pergunta: "Como você aprendeu tanto, Nasrudin?". E ele respondeu: "Falando muito. Eu vou falando, falando, falando, quando eu começo a ver o respeito no rosto do outro, eu começo a tomar nota mentalmente do que eu disse. Eu ouço aquilo que a pessoa não está dizendo, as reações do outro enquanto falo". Isso para mim é muito precioso na pedagogia teatral: perceber que aquilo que acontece no rosto do outro enquanto ele me escuta já me ensina muitas coisas.

$$
\text { [...] }
$$

Maria Clara Ferrer: Não sei se o silêncio que ouvimos é parasita ou se é prova de amor... Mas uma coisa é certa: a viagem entre Belo Horizonte e São João Del Rei ainda não chegou ao fim. Muito obrigada a todos.

Recebido em 12/10/2016 Aprovado em 28/10/2016

Publicado em 21/12/2016 